\title{
THE EFFECT OF QUALITY OF FOOD SOURCE ON MACADAMIA NUT DAMAGE BY Gymnandrosoma aurantianum (LEPIDOPTERA: TORTRICIDAE)
}

\author{
Helga Blanco-Metzler ${ }^{l * *}$, Allan D. Watt ${ }^{* *}$,Derek Cosens ${ }^{* * *}$
}

Keywords: Gymnandrosoma aurantianum, food quality, phenolics, macadamia, Costa Rica.

Palabras clave: Gymnandrosoma aurantianum, calidad de comida, fenoles, macadamia, Costa Rica.

Recibido: $21 / 08 / 12$

\section{ABSTRACT}

The effect of nitrogen content, the secondary compounds (tannin and proanthocyanidin) content, the dry matter content of 4 clones, and the different developmental stages of macadamia nuts, on the abundance of Gymnandrosoma aurantianum, was studied. Nitrogen content differed between clones and the stages of development of the nuts, being highest in the most tolerant clones $508>660>344>246$. Highest dry matter contents were found in the tolerant clones, 508 and 660, and in the outer layer, than in the susceptible clones 246 and 344 and in the inner layers (2 and 3). Proanthocyanidin content was highest in layer 2 of clones 508 and 660 than in clones 246 and 344. Results show that food quality affects the performance of nutborer larvae, where the larvae have to overcome first a physical barrier, followed by a chemical barrier, to be able to feed on macadamia nuts.
Aceptado: 31/05/13

\section{RESUMEN}

Efecto de la calidad de la fuente de alimento sobre el daño a la nuez de macadamia por Gymnandrosoma aurantianum (Lepidoptera: Tortricidae). Se estudió el efecto del contenido de nitrógeno, de los compuestos secundarios (taninos y prohantocianidinas) y de la materia seca de 4 clones de macadamia y de los diferentes estados de desarrollo de la nuez, sobre la abundancia de Gymnandrosoma aurantianum. El contenido de nitrógeno varió entre clones y los estados de desarrollo de la nuez, siendo más alto en los clones más tolerantes 508>660>344>246. Los mayores contenidos de materia seca se encontraron en los clones tolerantes, 508 y 660, y en las capas externas de la nuez, que en los susceptibles 246 y 344 y en las capas internas (2 y 3). El contenido de proantocianidinas fue mayor en la segunda capa de los clones 508 y 660 que en la de los clones 246 y 344. Los resultados muestran cómo la calidad del alimento afecta el desempeño de las larvas del barrenador, donde éstas, para alimentarse de la almendra, deben superar primero una barrera física, seguida por una barrera química.

\footnotetext{
** Centre for Ecology and Hydrology, Aberdeen, Scotland.

Zoology Department, Edinburgh University, Scotland.
} 


\section{INTRODUCTION}

Nut trees of the genus Macadamia spp. (Proteaceae) are native to Australian subtropical rainforests. Macadamia trees have been introduced and planted in many parts of the world, particularly in Hawaii, South Africa, Malawi, Guatemala, Brazil and Costa Rica (Nagao 2011).

The macadamia was introduced to Costa Rica in 1952, but it was not until 1965 that it started to be grown commercially as an alternative crop to coffee. The orchards were situated in plantations previously devoted to coffee (50-1200 masl). Macadamia exceeded all expectations in productivity. New orchards started to proliferate and soon it became a highly remunerative, non traditional export crop. At the present time, Costa Rica (3.5\%) is the world's fourth largest producer of macadamia, behind only Hawaii (53.1\%), Australia (27.9\%) and Kenya (3.6\%) (Bernal 2004).

With the excellent ecological conditions that Costa Rica offers for nut production, and the attractiveness of its international price, various government agencies as well as private banks have adopted generous incentive schemes to stimulate macadamia nut production. As the area used to grow macadamia increased, so have reports by producers of pest damage. One of the causes of damage to the nuts is Gymnandrosoma aurantianum (Lima) (Lepidoptera: Tortricidae) which tunnels into the nut and feeds on the kernel. The life cycle from egg to adult of the nutborer lasts nearly 36 days (Blanco et ál. 1993), so it is possible it could produce up to ten generations per year depending on the environmental conditions and food availability.

There are nine species of macadamia: Macadamia integrifolia, M. tetraphylla, M.ternifolia, M. claudiensis, M. grandis, M. hildebrandii, M. jansenii, M. whelanii, M. neurophylla; of these species, only integrifolia and tetraphylla have commercial value. Present commercial varieties are mainly grafted Hawaiian selections of $M$. integrifolia. The tetraphylla types are inferior in nut quality and are not accepted by processors, and the remaining types have a small and bitter nut (Wikipedia 2009). Of the many Hawaiian varieties developed, the most commonly grown in Costa Rica are clones Keahou (Haes 246), Kau (Haes 344), Kakea (Haes 508) and Keaau (Haes $660)$.

Blanco (1994) studied the biology and ecology of the macadamia nutborer and found out that female moths did not discriminate between clones during oviposition. However, clone susceptibility to G. aurantianum varied, suggesting that food quality was one of the factors limiting the insect's survival or growth, or both. Nitrogen is the plant nutrient which has been more clearly associated with a better insect performance; high nitrogen concentrations results in higher feeding (Horn 1988) and higher fecundity, while low nitrogen concentrations result in lower growth rates of insects (Wang et ál. 2006). Quantitative defences such as tannins, resins and lignins reduce the digestibility of plant tissues to herbivores (Rhoades 1983). Therefore, the aim of this study was to determine the effect on the abundance of Gymnandrosoma aurantianum of (i) the nitrogen content, (ii) the secondary compounds tannin and proanthocyanidin content; and the dry matter content of four clones and the different developmental stages of macadamia nuts.

\section{MATERIALS AND METHODS}

The field study was conducted at Oriente Farm, Turrialba, Costa Rica, 0953' N, 83⒋ $\mathrm{W}, 620$ to 700 masl. The mean annual rainfall during the period 1991-1993 was $2600 \mathrm{~mm}$; the mean temperature $22^{\circ} \mathrm{C}$, and the relative humidity around $80 \%$. Soils are classified as Inceptisols.

i) Nitrogen content. The present study was carried out at the physiology laboratory at CATIE (Centre for Tropical Agricultural Research and Education), Turrialba, Costa Rica. Nuts of four developmental stages: < 60 days; 60-75 days; 75-90 days; and 90-100 days, were harvested from trees of each clone, 246, 344, 508 and 660 every month. Each nut was split and the husk was dried for 8 hours at $105^{\circ} \mathrm{C}$. Dried husks $(25 \mathrm{mg})$ were ground to pass through a 40 mesh screen. 
Nitrogen content was analyzed by the modified micro-Kjeldhal methodology (Müller 1961), and was calculated by the formula:

$$
\begin{aligned}
& \% \mathrm{~N}=\frac{\mathrm{A} * \mathrm{~B} * \mathrm{C} * 100}{\mathrm{D}} \\
& \mathrm{A}=\mathrm{cm}^{3} \mathrm{H}_{2} \mathrm{SO}_{4} \\
& \mathrm{~B}=\text { acid normality } \\
& \mathrm{C}=\text { meq } \mathrm{N} \\
& \mathrm{D}=\text { sample weight }(\mathrm{g})
\end{aligned}
$$

The experimental design used was a randomized design. The significance of treatment effects was determined by analysis of variance (GLM), using SAS program (SAS 1985). The differences between means were calculated by the LSMeans test.

ii) Secondary compounds. Analyses were carried out at CATIE. This study used the same developmental stages of nuts described for the nitrogen analyzes, but included a fifth stage: $>100$ days. Nuts were split and separated into three layers: 1) the exo - and mesocarp; 2) the endocarp, and 3) the seminal coat, and placed in the freezer until analyzes were carried out. Each layer was broken into small pieces, and liofilyzed (freeze dried) for 12 hours. The layers were then ground to pass through a 40 mesh screen.

Tannin content. Soluble tannins were determined gravimetrically after precipitation with trivalent ytterbium (Reed et ál. 1985). Tannin content was calculated by the following formula:

$$
\% \text { Tannin }=\frac{[(\mathrm{E}-(\mathrm{C} * \mathrm{D}))]-(\mathrm{F}+\mathrm{G}-\mathrm{I})]}{\mathrm{A} * \mathrm{~B}} * 100
$$

$\mathrm{A}=$ sample weight $(\mathrm{g})$

$\mathrm{B}=$ dry matter sample $(\mathrm{g})$

$\mathrm{C}=$ filter weight $(\mathrm{g})$

$\mathrm{D}=$ dry matter filter weight $(\mathrm{g})$ at $105^{\circ} \mathrm{C}$

$\mathrm{E}=$ crisol + filter weight $(\mathrm{g})$ at $550^{\circ} \mathrm{C}$

$\mathrm{G}=$ crisol weight $(\mathrm{g})$

$\mathrm{I}=$ ash weight $(\mathrm{g})$ at $550^{\circ} \mathrm{C}$
Proanthocyanidin content. Soluble proanthocyanidins were determined by the Rittner and Reed (1992) methodology. Proanthocyanidins were not determined for layer 3 since the nut sample from the early developmental stages, $<60$ days and 60-75 days finished.

iii) Dry matter content. This study used the same developmental stages of nuts described in the secondary compound study. Dry matter content was determined from the difference between the initial and the final weight of the sample after 8 hours in an oven at $105^{\circ} \mathrm{C}$.

Data were analyzed using analysis of variance (SAS 1985) for a replicated split - plot design with two replicates, with clones as the main effect and stages of development as subplot. Layers were nested within the developmental stages. Differences between means were calculated by Tukey's Test. Tannin and dry matter data were transformed by $\arcsin v(\operatorname{tannin} / 100)$, and $\operatorname{arsin} v($ dry matter /100).

\section{RESULTS}

Nitrogen content varied significantly among clones $(\mathrm{F}=5.37 ; \mathrm{p}=<0.005)$, developmental stages $(\mathrm{F}=65.47 ; \mathrm{p}=<0.001)$ and between clones and stages of development $(\mathrm{F}=2.20 ; \mathrm{p}=<0.05)$ of the nut. It was higher in clone $508(1.66 \%)$ than the other tree clones: $660(1.52 \%) 246(1.50 \%) 344(1.46 \%)$. Nitrogen content decreased with nut maturation; it was highest in the first stage of development (1.93\%) followed by the stages of development $2(1.59 \%), 3(1.40 \%)$ and $4(1.21 \%)$ (Figure 1). Differences in nitrogen content between clones and developmental stages are shown in Figure 2. A similar pattern was observed for nitrogen content between the stages of development of the nuts within clones. No relationship was found between the percentage of nuts damaged and the percentage of nitrogen content of the nuts.

Tannin content ranged from 19 to $85 \%$. Highly significant differences in tannin content were found among clones $(\mathrm{F}=11.81 ; \mathrm{p}<0.001)$ and 


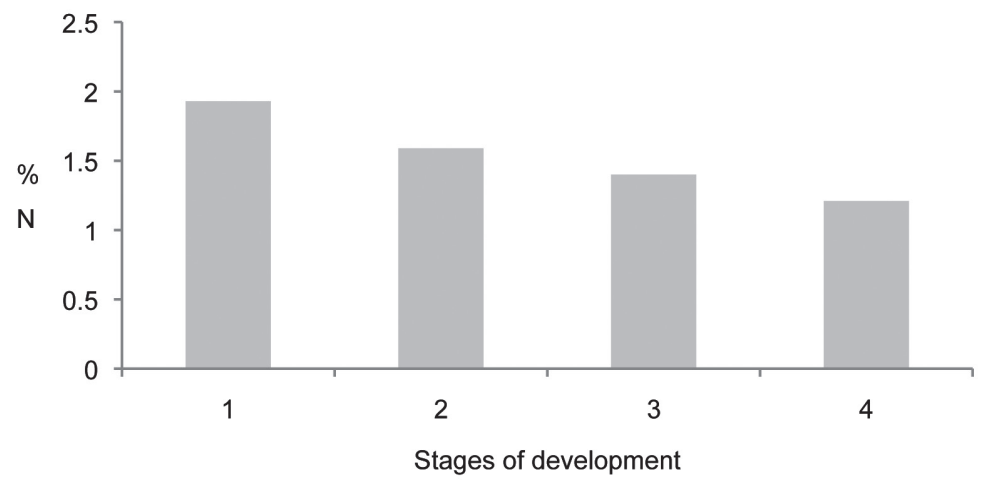

Fig. 1. Percentage of nitrogen content in four stages of development of macadamia nuts in Turrialba, Costa Rica.

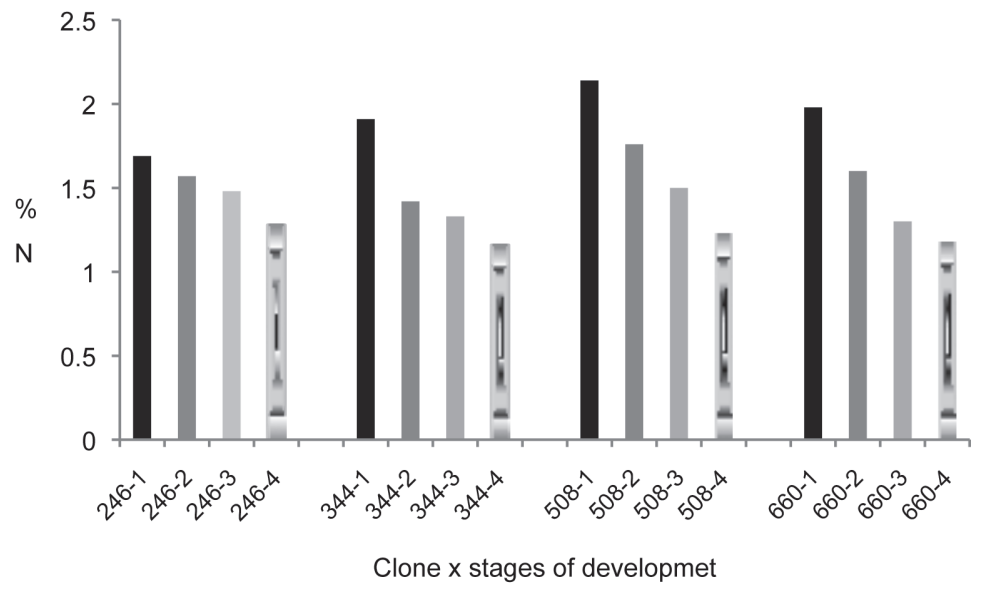

Fig. 2. Percentage of nitrogen in four clones and four stages of development of macadamia nuts in Turrialba, Costa Rica.

layers $(\mathrm{F}=13 ; \mathrm{p}<0.001)$, and significant differences were found between the stages of development $(\mathrm{F}=3.77 ; \mathrm{p}=0.02)$. However, the interaction between clones, layers and stages of development was also significant $(\mathrm{F}=2.58 ; \mathrm{p}<0.01)$. Therefore differences among variables cannot be explained.

No significant differences were found for proanthocyanidin content for the stages of development of the nuts $(\mathrm{p}=0.07)$. Proanthocyanidin content varied significantly between clones, being higher in clones 660 (5.73 abs) and 508 (3.66 abs) followed by 344 (2.25 abs) and 246 (1.90 abs) (Table 1). Tukey's test did not detect differences between the means for proanthocyanidin content of clones 660 and 508, or between the means of clones 508, 344 and 246. There was a significant difference between proanthocyanidin content for layers 1 and 2, being higher in layer 285.20 abs than in layer 1 (1.57 abs). A similar trend in proanthocyanidin content was observed for layers within clones (Table 1). However, there was a significant difference in proanthocyanidin content between clones and layers, interclonal differences were more marked in layers 2 than in layer 1 .

Percentage dry matter varied between clones at a highly significant level; it was highest in clones 660 (90.4\%) and $508(89.9 \%)$, followed by clones $344(87.5 \%)$ and $246(87.2 \%)$ (Table 2). 
Table 1. Means for proanthocyanidin content (abs) in four clones, two layers and between clones and layers, Turrialba, Costa Rica.

\begin{tabular}{clcccc}
\hline Clone & Mean & Layer & Mean & Clone x layer & Mean \\
\hline 660 & $5.73 \mathrm{a}$ & 2 & $5.20 \mathrm{a}$ & $660-2$ & $9.30 \mathrm{a}$ \\
508 & $3.66 \mathrm{ab}$ & 1 & $1.57 \mathrm{~b}$ & $508-2$ & $6.03 \mathrm{~b}$ \\
344 & $2.25 \mathrm{~b}$ & & $246-2$ & $2.83 \mathrm{c}$ \\
246 & $1.90 \mathrm{~b}$ & & $344-2$ & $2.62 \mathrm{c}$ \\
& & & $660-1$ & $2.16 \mathrm{c}$ \\
& & & $508-1$ & $1.88 \mathrm{c}$ \\
& & & $246-1$ & $1.28 \mathrm{c}$ \\
\hline
\end{tabular}

Means followed by the same letter are not significantly different $\mathrm{p}=0.05$.Tukey's test.

Table 2. Means for the dry matter content (mg) in four clones and three layers.

\begin{tabular}{cccc}
\hline Clone & Mean & Layer & Mean \\
\hline 660 & $90.40 \mathrm{a}$ & 1 & $96.95 \mathrm{a}$ \\
508 & $89.90 \mathrm{a}$ & 3 & $91.50 \mathrm{~b}$ \\
344 & $87.50 \mathrm{~b}$ & 2 & $90.22 \mathrm{~b}$ \\
246 & $87.26 \mathrm{~b}$ & & \\
\hline
\end{tabular}

Means followed by the same letter are not significantly different $\mathrm{p}=0.05$. Tukey's test.

No significant differences were found between the stages of development for dry matter content. Dry matter content between layers varied significantly, being highest in layer 1 (96\%) than in layers $3(91.5 \%)$ and $2(90.2 \%)$. Tukey's test did not detect differences between the means of layers 2 and 3.

\section{DISCUSSION}

The development of phytophagous insects often depends on the physiological condition of the plant. Nitrogen content is regarded as a critical aspect of plant quality because it is often a limiting nutrient for both plants and herbivorous insects (Mattson 1980). The reproductive success of insects depend to a large extent on their ability to ingest, digest and convert plant nitrogen efficiently and rapidly. A high nitrogen supply may increase protein production and decrease the carbohydrate content resulting in the formation of thin cell walls and softer and succulent tissue, which make the plant more susceptible to insect feeding (Southwood 1972). A high nutritious quality of the plant has been found to increase nymph development and survival, and hence overall abundance of an insect (Groenteman et ál. 2006). Nitrogen content differed between clones and the stages of development of the nuts. Since nitrogen content is associated with more nutritious food and differed between clones and developmental stages of the nuts, higher levels of nitrogen were expected in the susceptible clones 246 and 344 than in the tolerant clones 508 and 660 (Dwomoh et ál. 2008). Therefore, this result suggests, that moths are not attracted to lay eggs on a more nutritious food source, thus supporting the hypothesis that $G$. aurantianum is a native species which recently switched to macadamia nuts. Nitrogen concentration influences host plant choice (Athey and Connor 1989, Moravvey and Hatefi 2008) and oviposition (Wang et ál. 2006). Higher herbivory has been found among closely-related plants with higher foliar nitrogen 
concentrations (Tabashnik 1982, Daane et ál.. 1995). Variability in the growth and survival of the pine beauty moth, Panolis flammea Dennis and Schiffermüller (Lepidoptera: Noctuidae) was found to be positively correlated with foliar nitrogen of lodgepole pine and Scots pine (Watt 1990). Wang et ál. (2006) studied the effect of high nitrogen fertilizer doses on corn plants on Peregrinus maidis (Homoptera: Delphacidae) performance. They found out that insects that developed on corn plants which received high nitrogen fertilization had a shorter developmental time, a higher immature survival rate, a greater adult mass, and laid significantly more eggs.

The fact that nitrogen content decreased with nut maturation is consistent with what has been reported in the literature. Higher concentrations of nitrogen occur in actively growing tissues or storage tissues, such as seeds. Such tissues require high nitrogen levels to support rapid protein synthesis during bursts of growth. As tissue growth begins to wane, so does nitrogen content (Mattson 1980) Since G. aurantianum discriminate against small nuts $(<8 \mathrm{~mm}$ in diameter) for egg laying (Blanco et ál. 1993), it may be that on their previous host(s), they lay eggs on fruits larger than $8 \mathrm{~mm}$ in diameter.

Higher dry matter contents were found in the tolerant clones, 508 and 660, and in the outer layer than in the susceptible clones 246 and 344 and the inner layers (2 and 3). This observation suggests that larval survival is primarily affected by a physical barrier; as the husk matures, it gets drier and is more difficult to chew. Coley (1983) studied the rates of herbivory and defense characteristics of young and mature leaves of 46 tree species in a lowland tropical forest. He found that leaf toughness and fiber content were the most important characteristics which determined grazing levels and suggested that the importance of phenolic content as a defense may have been over emphasized. At the same time, the hardness of plant tissues may affect fecundity of insects by affecting feeding or oviposition. Iheagwam (1981) found an inverse relationship between fecundity of the cabbage whitefly, Aleyrodes brassicae
Walk. (Homoptera:Aleyrodidae) and leaf toughness. Tougher surfaces will imply that larvae need more time to bore through the husk which will expose them for longer periods to predators and parasitoids.

Proanthocyanidin content was highest in layer 2 of clones 508 and 660 than in clones 246 and 344, representing another potentially detrimental on larval survival. Larvae have to overcome this defensive characteristic to feed on the husk or to be able to bore through the kernel. Proanthocyanidins may lower the nutritive value of plant tissue (Dixon et ál. 2005, Mellway and Constabel 2009). However they can inhibit herbivore feeding in various ways including direct enzyme inhibition or by forming indigestible complexes with leaf proteins. Similar results were found by Osier and Lindroth (2001) who found that the primary source of variation of gypsy moths Lymantria dispar Linnaeus (Lepidoptera: Lymantriidae) performance on quaking aspen (Populus tremuloides) was due to plant genotype (phenolic glycosides levels), while foliar nitrogen levels were of secondary importance.

Blanco et ál. (1993) found that G. aurantianum did not discriminate between clones during oviposition. However, in this study, clone susceptibility to G. aurantianum varied, suggesting that food quality was one of the factors limiting the insect's survival or growth, or both. In the study, nitrogen and tannin content did not affect the abundance of the nutborer, while higher proanthocyanidin and dry matter contents were found in the tolerant clones. Since dry matter was highest in the exocarp and mesocarp of the nuts from the tolerant clones and proanthocyanidines were highest in the endocarp, the nutborer larvae have to overcome first a physical barrier followed by a chemical barrier to feed on macadamia nuts. Various results from Blanco et ál. (1993, 1997, 2007, 2009), lead to the conclusion that G. aurantianum is an indigenous species to Costa Rica, which switched to macadamia due to it being a more abundant food source. 


\section{ACKNOWLEDGEMENTS}

This research was financed by the British Council and the Tropical Agricultural Research and Training Centre, CATIE.

\section{LITERATURE CITED}

ATHEY L.A., CONNOR E.F. 1989. The relationship between foliar nitrogen content and feeding by Odonata dorsalis Thun. on Robinia pseudoacacia L. Oecologia 79:390-394.

BERNAL M. 2004. La macadamia, alternativa de diversificación en el país. Dirección de Mercadeo y Agroindustria, Servicio de Información, Consejo Nacional de Producción (CNP). Consultado agosto 2012. Disponible en: http://www.mercanet.cnp.go.cr

BLANCO H. 1994. The biology and ecology of the macadamia nutborer Ecdytolopha torticornis in Costa Rica. PhD Thesis, University of Edinburgh, Scotland. $132 \mathrm{p}$.

BLANCO H., VILLALOBOS R., WATT A.D., COSENS D. 1997. Efecto del manejo de malezas en macadamia sobre la población del barrenador de la nuez Ecdytolopha torticornis Meyrick (Lepidoptera: Tortricidae). Agronomía Mesoamericana 8(2):96100.

BLANCO H., WATT A.D., COSENS D. 1993. Ciclo de vida y comportamiento de oviposición de Ecdytolopha torticornis (Lepidoptera: Tortricidae) barrenador de la nuez de macadamia. Revista Manejo Integrado de Plagas 29:36-39.

BLANCO H., WATT A.D., COSENS D. 2007. The effect of predators on the population dynamics of Ecdytolopha torticornis Meyrick (Lepidoptera: Tortricidae). Agronomía Costarricense 31(1):33-39.

BLANCO H., WATT A.D., COSENS D. 2009. The effect of parasitism on the population dynamics of Gymnandrosoma torticornis (Lepidoptera: Tortricidae). Revista Biología Tropical 57(4):12451252.

COLEY P.D. 1983. Herbivory and defensive characteristics of tree species in a lowland tropical forest. Ecological Monographs 53(2):209-233.

DAANE K.M., JOHNSON R.S., MICHAILIDES T.J. CRISOSTO C.H., DLOTT J.W., RAMIREZ H.T., YOKOTA G.Y., MORGAN D.P. 1995. Excess nitrogen raises nectarine susceptibility to disease and insects. California Agriculture 49(4):13-18.

DIXON R.A., XIE D.Y., SHARMA S.B. 2005. Proanthocyanidins-a final frontier in flavonoid research? New phytologist 165(1):9-28.

DWOMOH E.A., OFORI-FRIMPONG K., AFRIFA A.A., APPIAH M.R. 2008. Effects of fertilizar on nitrogen contents of berries of three coffee clones and berry infestation by the coffee berry borer, Hypothenemus hampei (Ferr.) (Coleoptera: Scolytidae). African Journal of Agricultural Research 3(2):111-114.

GROENTEMAN R., GUERSHON M., COLL M. 2006 Effects of leaf nitrogen content on oviposition site selection, offspring performance, and intraspecific interactions in an omnivorous bug. Ecological Entomology 31:155-161.

IHEAGWAM E.U. 1981. The relationship between weight of insect, age, hardness, and nitrogen content of cabbage leaves and fecundity of the cabbage whitefly, Aleyrides brassicae Wlk. (Homoptera:Aleyrodidae). Zeitschrift fur Angewandte Entomologie 91:349-354.

MATTSON W.J. 1980. Herbivory in relation to plant nitrogen content. Annual Review of Ecology and Systematics 11:119-161.

MELLWAY R.D., CONSTABEL C.P. 2009. Metabolic engineering and potential functions of proanthocyanidines in poplar. Plant Signaliong and Behaviour 4:8, 790-792.

MORAVVEY GH.H., HATEFI S. 2008. Role of nitrogen content of pea (Pisum sativum L.) on pea aphid (Acyrthosiphon pisum Harris) establishment. Caspian Journal of Environmental Science 6(2):113131.

MÜLLER L. 1961. Un aparato micro-Kjeldhal para análisis rutinarios rápidos de materiales vegetales. Turrialba 11(1): $17-25$.

NAGAO M.A. 2011. Farm and Forestry Production and Marketing Profile for Macadamia Nut (Macadamia integrifolia and M.tetraphylla). Speciality Crops for Pacific Island Agroforestry. Permanent Agriculture Resource (PAR) Holualoa, Hawaii. 19 p.

OSIER T.L., LINDROTH R.L. 2001. Effects of genotype, nutrient availability and defoliation, on aspen phytochemistry and insect performance. Journal of Chemical Ecology 27(7):1289-1313.

REED J.D., HORVATH P.J., ALLEN M.S. VAN SOEST P.J. 1985. Gravimetric determination of soluble phenolics including tannins from leaves by precipitation with trivalent ytterbium. Journal Science Food Agriculture 36:255-261.

RHOADES D.F. 1983. Herbivore population dynamics and plant chemistry, pp. 155-220. In: R.F. Denno and M.S. McClure (eds.). Variable plants and herbivores in natural and managed systems. New York, Academic Press.

RITTNER U., REED J.D. 1992. Phenolics and in-vitro degradability of protein and fiber in West African Browse. Journal Science Food Agriculture 58:21-28.

SAS INSTITUTE. 1985. SAS user's guide: statistics, version 5,1. Cary North Carolina, SAS Institute.

SOUTHWOOD T.R.E. 1972. The insect/plant relationship - an evolutionary perspective. In: Insect/Plant 
Relationship (van Emden H.F., ed.). Symposium. Review of Entomological Society, London 6:3-30.

TABASHNIK B.E. 1982. Response of pest and non-pest Colias butterfly larvae to intraspecific variation in leaf nitrogen and water content. Oecologia 55:389-394.

WANG J.J. TSAI J.H. BROSCHAT TK. 2006. Effect of nitrogen fertilization of corn on the development, survivorship, fecundity and body weight of
Peregrinus maidis (Homoptera:Delphacidae). Journal of Applied Entomology 130(1):20-25.

WATT A.D. 1990. The consequences of natural, stressedinduced and damaged-induced differences in tree foliage on the population dynamics of the pine beauty moth, pp. 157-168. In: A.D. Watt, S.R. Leather, M. Hunter and N.A.C. Kidd (eds.). Population dynamics of forests insects. Andover, Hampshire, Intercept.

WIKIPEDIA. 2009. Macadamia. Consultado 17 agosto 2012. Disponible en: http://en.wikipedia.org 